\title{
On the formation of energy policies towards 2020: Challenges in the Swedish industrial and building sectors
}

\author{
Patrik Thollander, Patrik Rohdin and Bahram Moshfegh
}

\section{Linköping University Post Print}

N.B.: When citing this work, cite the original article.

Original Publication:

Patrik Thollander, Patrik Rohdin and Bahram Moshfegh, On the formation of energy policies towards 2020: Challenges in the Swedish industrial and building sectors, 2012, Energy Policy, (42), 461-467.

http://dx.doi.org/10.1016/j.enpol.2011.12.012

Copyright: Elsevier http://www.elsevier.com/

Postprint available at: Linköping University Electronic Press

http://urn.kb.se/resolve?urn=urn:nbn:se:liu:diva-77107 


\title{
On the formation of energy policies towards 2020: \\ challenges in the Swedish industrial and building
}

\author{
sectors \\ Patrik Thollander ${ }^{a, *}$, Patrik Rohdin ${ }^{\text {a }}$, Bahram Moshfegh ${ }^{\text {a }}$ \\ ${ }^{a}$ Department of Management and Engineering, Division of Energy Systems, \\ Linköping University,
}

SE-581 83 Linköping, Sweden

\begin{abstract}
The impact of global climate change due to increased emissions of greenhouse gases emissions which in turn is a consequence of in particular, the use of fossil fuels, has made EU decision makers to act decisively, e.g. the EU 2020 primary energy target of reducing primary energy use with $20 \%$ from 2005 to 2020 . The aim of this paper is to present major challenges related to the development and formation of energy policies towards the Swedish industrial and building sector in order to fulfil the EU 2020 primary energy target. This paper is approaching the presented challenges by introducing the theory of Asymmetric Energy Policy Shocks (AEPSs), and addresses some key challenges which are of particular relevance for the fulfilment of the EU 2020 primary energy target for Member States like Sweden which from an energy end-use perspective substantially differs from the EU-25's energy end-use structure. In conclusion, overcoming AEPSs, and moving towards a more Long-Term Energy Policy Approach (LTEPA) will be of key importance for individual Member States, if the 2020 primary energy target is to be fulfilled.
\end{abstract}

\footnotetext{
* Corresponding author. Fax: + 46-13-28 1788

E-mail address: patrik.thollander@liu.se (P. Thollander).
} 
Keywords: EU 2020 Primary Energy Target, Industrial and Building sectors, Asymmetric Energy Policy Shocks (AEPSs)

\section{Introduction}

The impact of global climate change due to increased emissions of greenhouse gases emissions which in turn is a consequence of in particular, the use of fossil fuels, has made EU decision makers to act decisively. In 2006, the European Union presented its Energy End-Use Efficiency and Energy Services Directive (ESD) which aims to reduce energy end-use in the non-trading parts of the Economy by $9 \%$ to 2016, beginning from 2008 (EC, 2006a). The directive gives the existence of barriers to energy efficiency a central role and in particular the elimination of market barriers and market imperfections.

In October 2006, the EU 2020 Energy Efficiency Action Plan (EEAP) was launched presenting a primary energy saving target of $20 \%$ in 2020 compared to a projected level from the year 2005 (EC, 2006b). The energy intensity in the EU should be reduced by 3.3 $\%$ per year. The baseline projection is an increase in primary energy use of $0.5 \%$ per year, if structural effects, autonomous effects and the effects of previous policy are taken into account. If these were not taken into account, the primary energy use is expected to rise with $2.3 \%$ per year, i.e. a decreased energy intensity of $1.8 \%$ per year is expected due to previous policy $(0.35 \%$ per year) structural effects $(0.6 \%$ per year) autonomous effects ( $0.85 \%$ per year). From the $0.5 \%$ per year baseline projection of the EU primary energy use up to 2020 , yet another $1.5 \%$ energy intensity reduction is demanded, in addition to the prevailing trend of $1.8 \%$ decrease per year. The $1.5 \%$ energy intensity reduction should, according to the EC (2006b) come from the impact of new policy and new policy beyond directive (EC, 2006b).

In the Swedish Government Bill (GB, 2009) Sweden describes its national energy for 2020. The formulation is that: "A goal of $20 \%$ increased energy efficiency should be set 
up in 2020. The goal is expressed as a sector-wide target of reducing energy intensity of 20 $\%$ between 2008 and 2020, calculated as energy in relation to GDP (in constant prices). The goal for 2020 is set to be an energy intensity decrease of $1.7 \%$ per year" (GB, 2009).

Regarding the development of energy intensity in Sweden, from 1983 to 2007, it has declined by $1.2 \%$ per year. Since 1990 the rate has averaged about $1.5 \%$ per year, to return to around $1.2 \%$ per year between $2000-2007$ (GB, 2009).

One significant difference between the Swedish and the EU goal settings are that the base years are different. The EU's base year is 2005 and Sweden's is 2008. Another difference is that the Swedish formulation is considered fulfilled if the energy intensity decreases by about $1.7 \%$ per year (GB, 2009). No discussion is held in the Swedish Government Bill (GB, 2009) on the effects of structural effects, autonomous actions and effects of previous instruments. Neither is an explanation given why Sweden's targets are set below the EU's. In summary it appears that Sweden's targets are less ambitious than the EU's.

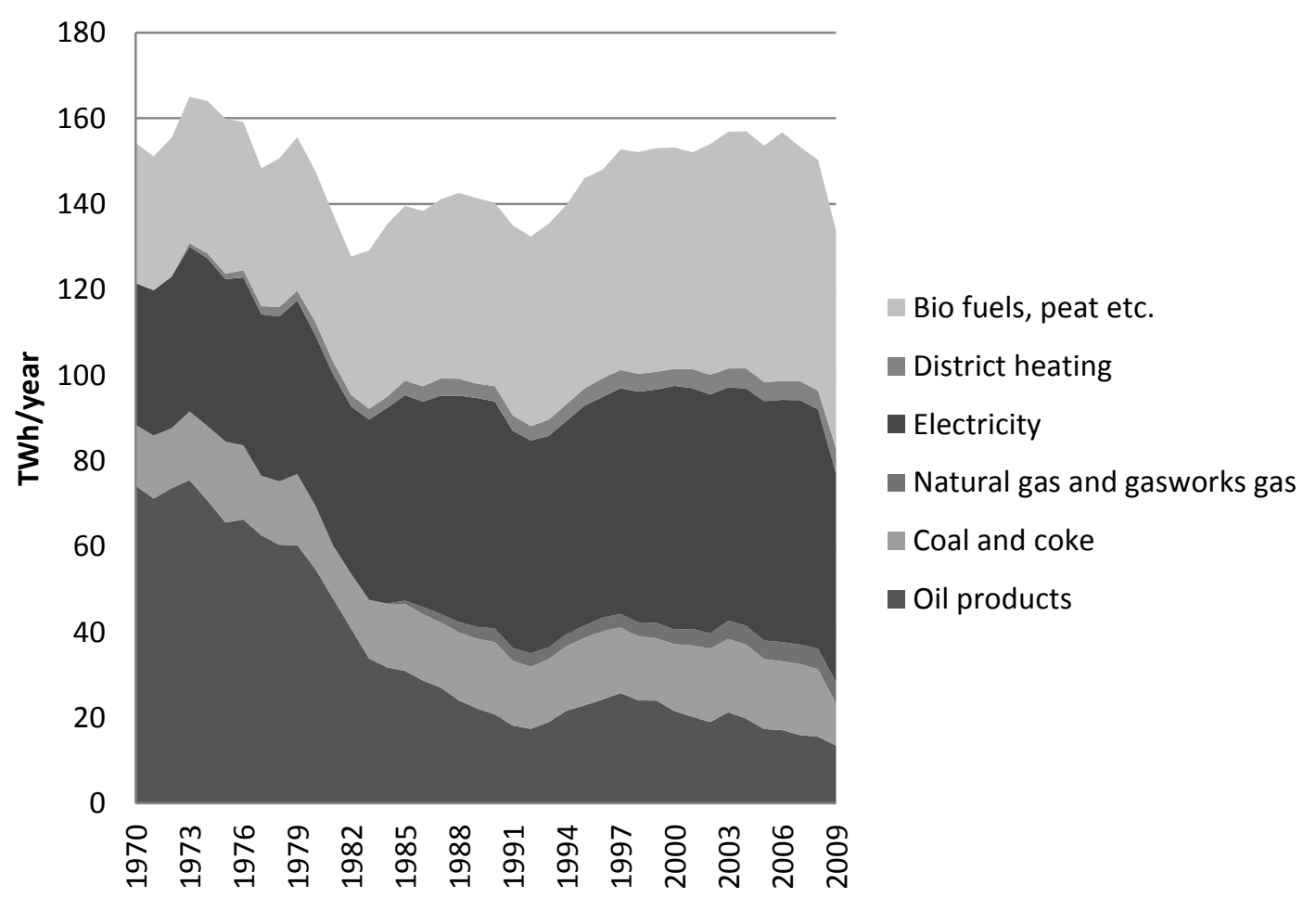

Fig. 1. The Swedish industrial sector's energy end-use 1970-2009 (SEA, 2010a). 


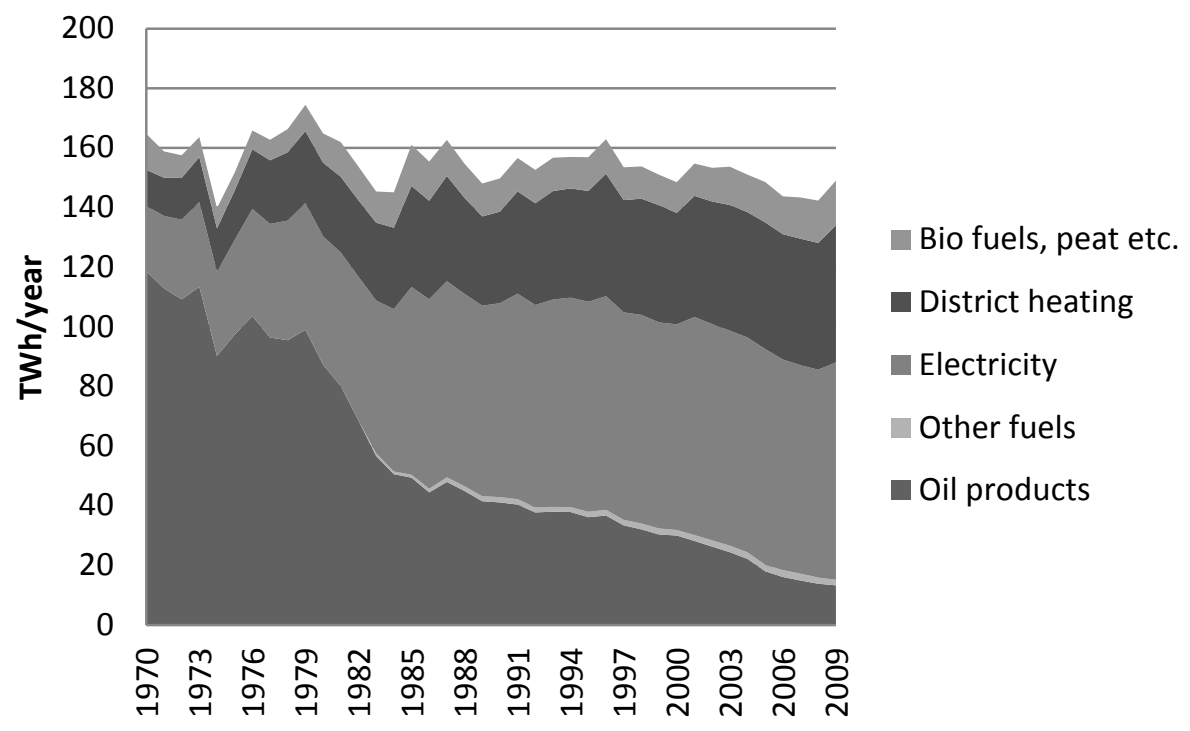

Fig. 2. The Swedish building sector's energy end-use 1970-2009 (SEA, 2010a).

The degree of Renewable Energy Sources (RES) in the EU-25 in 2020 is targeted to be $20 \%$ of the total energy supply. Fig 1. and Fig 2. displays the energy end-use in the Swedish building and industrial sectors.

The figures show that there has been a major conversion from oil to other energy carriers, mainly to electricity. This in turn is due to major policy programs adopted during the oil crisis in the 70ies, and onward, to reduce dependency on fossil fuels, primarily oil. Fig. 1 and Fig. 2 also displays the major use of RES in the Swedish energy mix in the industrial and building sectors, a major deviation compared with the EU-25's energy enduse of RES. The Sweden's total proportion of renewable energy use between 1990 to 2009 increased from $33 \%$ to $45 \%$, compared with EU-25's proportion of renewable energy of $4.5 \%(1990)$ and $10.3 \%(2008)$.

The Swedish building and industrial sectors, have, as a consequence of the deregulation of the Swedish electricity market, faced large electricity price increases, see Fig. 3. These increases have taken place from very low price levels, e.g. Sweden had in the beginning of the 21th century the lowest electricity prices in the European Union (EEPO, 2003). 
In addition to that, Sweden which major power supplies have low operation costs, e.g. hydro and nuclear power, the low prices have made consumers choose electricity above other energy carriers, leading to the EU's largest per capita use of electricity. From an individual household or company's point of view, new policies enabling a more efficient energy use, is thus much sought after.

\section{Electricity prices on Nord Pool}

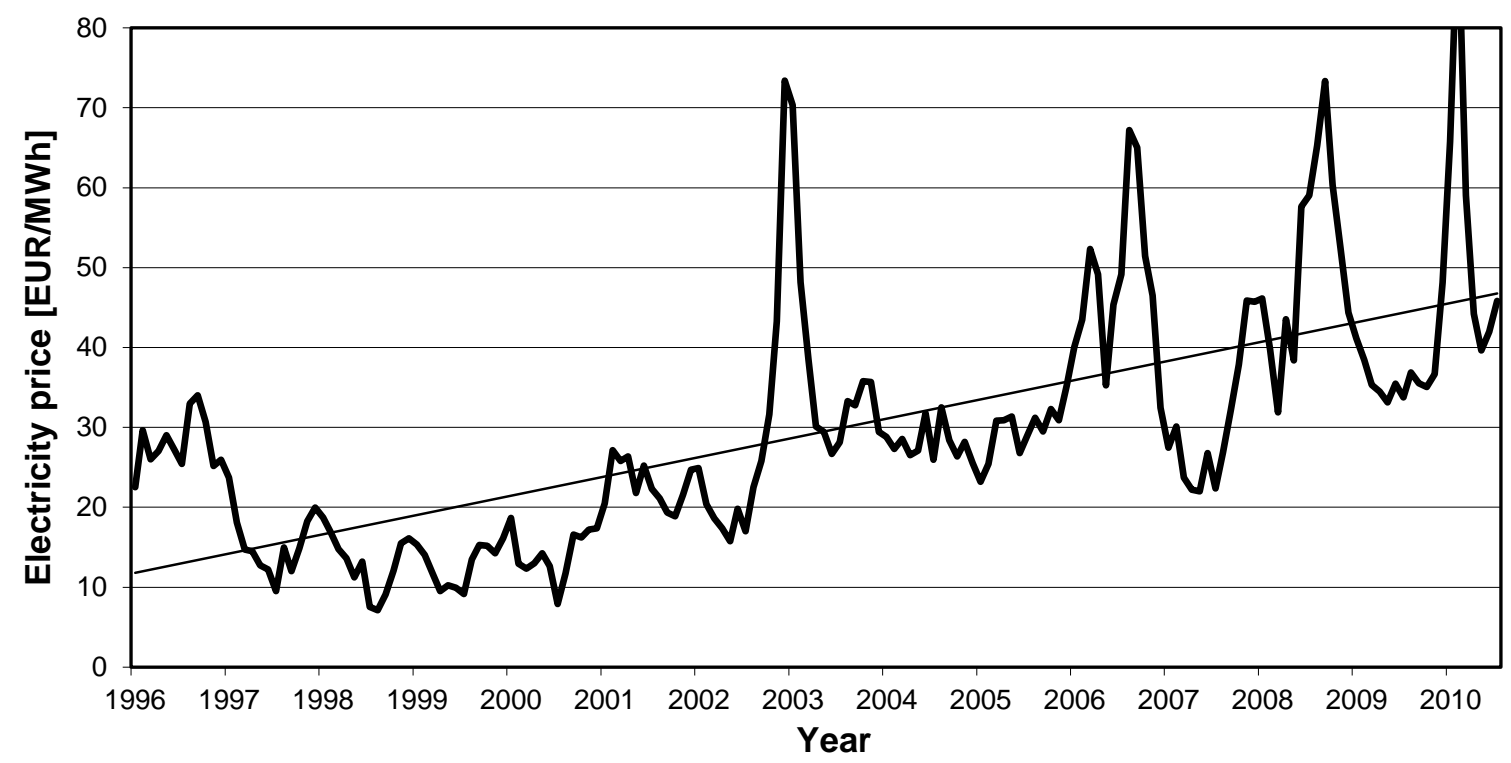

Fig. 3. The electricity spot prices for Swedish customers on the Nordic Electricity Spot Market (Nordpool, 2011).

It is shown in Fig. 3. that the prices on electricity have greatly increased. From an initial decrease following the deregulation of the Swedish electricity market in 1996, prices started to increase from the year 2000. This was due to an extension of the market including Norway, Denmark, and Finland, i.e. the formation of the Nordic electricity market.

The energy efficiency potential is stated to be $25 \%$ for the European industrial sector and $27 \%$ for the European building sector (EC, 2006b). In a report, written on behalf of the European Commission, Wesserlink et al. (2010), showed that the effect of European energy policies needs to be tripled in order fulfil the EU 2020 primary energy target: 
"Our study concludes that closing this gap requires a threefold increase in policy impact compared to energy savings policies adopted since the 2006 EEAP (Energy Efficiency Action Plan).” (Wesserlink et al., 2010).

It is thus evident that the development and formation of effective new energy policies is of crucial importance if the 2020 primary energy targets are to be reached. The aim of this paper is to present major challenges related to the development and formation of energy policies towards the Swedish industrial and building sector in order to fulfil the EU 2020 primary energy target. The paper is approaching the presented challenge by introducing the theory of Asymmetric Energy Policy Shocks (AEPSs). The paper result shows that AEPSs will be a major challenge for some Member States to overcome, if the EU 2020 primary energy target is to be reached. The paper is delimited to the Swedish industrial and building sectors and does not include the transport sector, or the decisionmaking process within the government. The reason for the latter, is exemplified by Fig. 4.

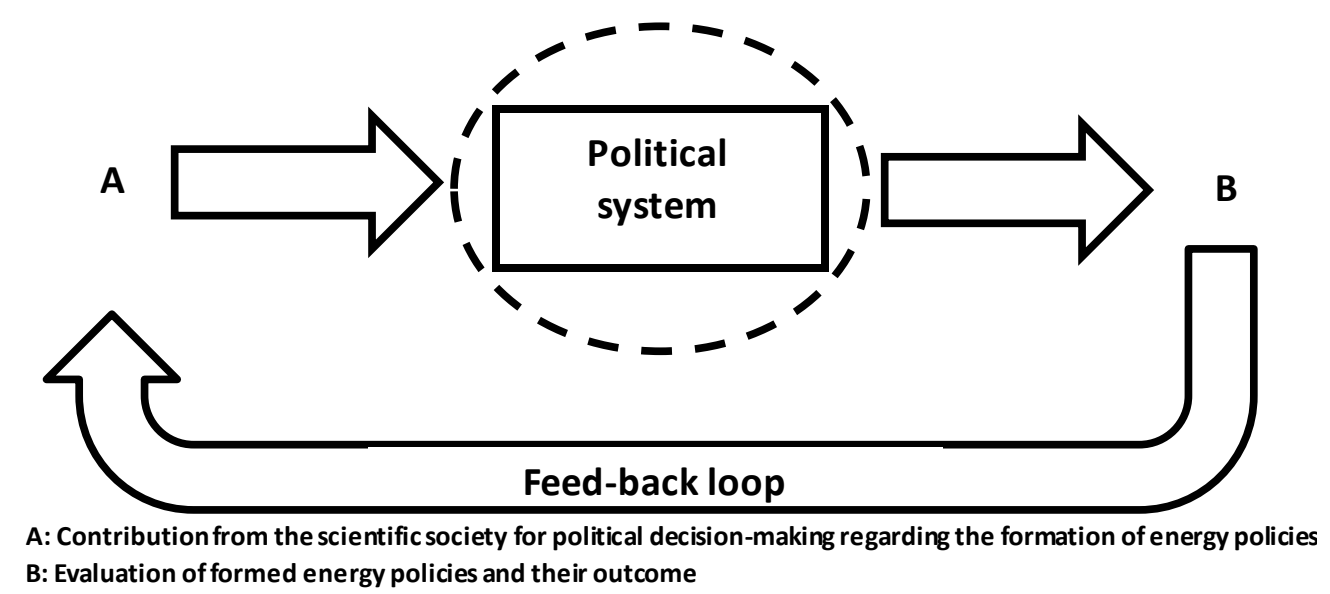

Fig. 4. A simplified model for political decision-making and the impact from the scientific society. The dashed line represents the system boundary on how far scientific research can make contribution to energy policy decision-making (based on Vedung, 1998). 
The figure shows a simplified model on how the scientific society can make contribution to the energy policy formation process in a Swedish context.

The systems approach according to Churchman (1968) begins when viewing an issue from another angle or perspective. Churchman (1968) gives examples of how a number of the problems in the world could be approached and solved with tools already at disposal, but which still remains unsolved, due to lack of a systems approach. This paper aims to take a systems approach illuminating the key challenges of fulfilling the EU 2020 primary energy target from a number of perspectives. The paper's contributions to the energy policy research discourse is the introduction of the term AEPSs and the presentation of a number of individual Member State-related challenges, mainly from a Swedish perspective, derived from the concept of AEPSs and which to the author's awareness, not previously has been covered in the scientific energy policy literature.

\section{Energy policy instruments}

When new energy policies are designed, it often relies upon economic theory. The theory states that in order for a policy to be considered, market imperfections/market failures should have been detected. Moreover, the considered policy should pass a costbenefit test showing that the cost for the public intervention does not exceed the benefits.

One may categorize market failures into four broad types, incomplete markets, imperfect competition, information imperfections and asymmetries, among where the latter are of primary interest in regard to energy end-use efficiency. This view of energy policy decision-making may inhibit energy efficiency, as stated in e.g. Palm and Thollander (2010): "In summary, barriers to energy efficiency which may be classified as market failures or market imperfections may lead to policy adoption, while so called market barriers, which may be classified as any barrier which accounts for the energy efficiency gap, may not promote policy adoption. The classification of barriers thus has strong 
implications in regard to if, how, and when, a policy is to be adopted." (Palm and Thollander, 2010).

Energy policies are normally categorized into economic policy instruments, like taxes, duties, subsidies, financial incentives etc, administrative policy instruments like rules and regulations, acts etc, and informative policy instruments like information campaigns/programs (Swedish Ministry of Enterprise, Energy and Communications, 2001). Table 1 present a general overview of current Swedish energy policies in place (SEA, 2010a).

Table 1

General overview of Swedish policies in place (SEA, 2010a).

\begin{tabular}{llll}
\hline Administrative & Economic & Informative & Research \\
\hline Regulations & Taxes & Information & Research \\
\hline $\begin{array}{l}\text { Limit values (emissions) } \\
\begin{array}{l}\text { Fuel type and energy } \\
\text { efficiency requirements }\end{array}\end{array}$ & Subsidies, grants & Advisory services & Development \\
$\begin{array}{l}\text { Sureties } \\
\text { EU Emission trading } \\
\text { scheme }\end{array}$ & Training & Demonstration \\
$\begin{array}{l}\text { Environmental } \\
\text { classification }\end{array}$ & $\begin{array}{l}\text { Electricity certificate } \\
\text { scheme }\end{array}$ & Opinion-forming & Commercialization \\
\hline
\end{tabular}

In relation to the Swedish industrial and building sectors, there are a number of current economic energy policy instruments in place such as (SEA, 2010a):

- Maintenance, renovation or rebuild and expansion in the building sector

- Support for conversion from oil and electricity-based space heating in residential buildings

- Support for installation of more energy-efficient windows

- Support for installation of bio-fuel facilities in residential buildings

- Support for energy efficiency and conversion of premises used for public activities 
- Program for improving energy efficiency in energy-intensive industry (PFE)

- Energy auditing program

Towards the Swedish industrial and building sectors there are also a number of administrative energy policy instruments in place such as (SEA, 2010a):

- The environmental code is a mandatory and comprehensive instrument for environmental protection and covers all environmentally harmful activities and operations

- Energy requirements in building regulations such as the directives from Swedish National Board of Housing, Building and Planning

- Energy Performance Certificate

- Eco-design and energy labelling

- Regulation of energy-efficient state agencies

Also a number of informative energy policy instruments are directed towards the Swedish industrial and building sectors such as (SEA, 2010a):

- Local authority energy and climate consultant

- Regional energy agencies

- Building-Living dialogue

- Renovate energy smart

- Information and advice portal for energy efficiency in residential buildings and services

- Applications for buildings with low energy usage

In regard to informative energy policy instruments there are also a number of networks such as sustainable municipalities, industrial energy controller networks in various sectors 
etc. It should be noted that the above presentation of Swedish policy instruments is not a full presentation and that the categorization is not unambiguous, i.e. policy instruments like, e.g. the PFE towards industry may be categorized as both an economic and an informative policy.

Apart from economic-, administrative-, and informative-based energy policies, one may also include a fourth, namely research-based energy policies. Research-based energy policies are used in order to develop new more energy-efficient technologies, both products and processes, and are derived from research of technological development ${ }^{1}$. In short, research of technological developments show that development is taken in steps. When a new technology has been invented and reached the market, it follows a pattern where major innovations are taken place, first in the area of the actual technology or product, and as the product and the market develops, innovations are taken place also in relation to the process. The initial phase of technology development is characterized by a large number of smalland medium-sized entrepreneur-like firms. As the product and market becomes more mature, the number of major innovations in the product and the process slowly decrease.

During this mature phase the majority of the manufacturers have, due to competitive reasons, been forced to leave the market, and the market is characterized by large manufacturers with a very cost-efficient manufacturing process.

2.1 Outcome of Swedish energy policy instruments for the building and industrial sectors

In the second Swedish action plan, the policy outcomes for the industrial and building sectors are presented. The outcome is presented in Fig 5. and Fig. 6. 


\begin{tabular}{lll}
\hline $\begin{array}{l}\text { Policy effects, second Swedish } \\
\text { action plan, industrial sector }\end{array}$ & $\begin{array}{l}\text { 2010 } \\
\text { (TWh) }\end{array}$ & $\begin{array}{l}\text { 2016* } \\
\text { (TWh) }\end{array}$ \\
\hline $\begin{array}{lll}\text { Early policies } \\
\text { PFE, 1st period }\end{array}$ & 0.4 & 0.4 \\
Late policies & & \\
Top-down calculation 2007-2016** & 4.6 & 15.0 \\
PFE, 2st period & 1.0 \\
Energy audit program & 1.0 \\
\hline Sum & $\mathbf{5 . 0}$ & $\mathbf{1 7 . 4}$ \\
\hline *Ex-ante & & \\
** The top down caclulation includes the effects from, e.g.taxes, \\
the EU ETS etc.
\end{tabular}

Fig. 5. Policy outcomes presented in the second Swedish action plan (SEA, 2010b).

\begin{tabular}{lll}
\hline $\begin{array}{l}\text { Policy effects, second Swedish action plan, building } \\
\text { sector }\end{array}$ & $\begin{array}{l}\mathbf{2 0 1 0} \\
\text { (TWh) }\end{array}$ & $\begin{array}{l}\mathbf{2 0 1 6} \\
\text { (TWh) }\end{array}$ \\
\hline Early policies & 1.60 & 1.60 \\
Energy efficienct windows and insulation & 14.40 & 12.50 \\
Conversion & 0.08 & 0.08 \\
Solar cells and solar cells & 1.50 & 0.85 \\
Energy efficient appliances & 3.09 & 1.22 \\
Energy efficient lighting & & \\
Late policies & 0.56 & 1.70 \\
Energy efficienct windows and insulation & 1.10 & 3.40 \\
Conversion & 0.06 & 0.16 \\
Solar cells and solar cells & 0.20 & 0.60 \\
Energy efficient appliances & 0.62 & 2.38 \\
Energy efficient lighting & $\mathbf{2 3 . 2}$ & $\mathbf{2 4 . 5}$ \\
\hline Sum & &
\end{tabular}

Fig. 6. Policy outcomes presented in the second Swedish action plan (SEA, 2010b).

The results show that the major savings in the industrial sector are not allocated towards a specific policy, e.g. the major savings from the industrial sector are derived from 
a top-down calculation, while this is not the case for the building sector. These results reveals that for the industrial sector, the impact of taxes, the Swedish electricity certificate scheme, the EU ETS and other policy instruments are all included in the top-down calculation, and thus, are not explicitly stated. The same challenge is stated by Wesserlink et al. (2010) in a report by the European Climate Foundation (ECF):

"Our calculations suggest that the additional fuel savings, compared to the baseline assumptions, expected from EU-ETS covered facilities is comparatively small.... Note that we cannot make any findings about the impact of the carbon price incentives on energy savings, given the prevailing market barriers and other factors...". (Wesserlink et al., 2010).

\section{Asymmetric Energy Policy Shocks (AEPSs)}

An asymmetric shock in a monetary union refers to an occurrence of effects in one part of the union which are not taken place in another part. The risk of asymmetric shocks was one of the major reasons why the Swedish investigation before the choice of entering EMU or not, was slightly pessimistic to entering the union (EMU-investigation, 1996). In this paper, a new term is introduced named Asymmetric Energy Policy Shocks (AEPSs). AEPSs are defined as a strong effect of an energy policy in one part of a region or sector while other regions and sectors remain less affected. The sections below briefly introduces the term in relation to some of the key challenges related to Member State and EU energy policy development and formation to reach the EU 2020 primary energy target.

\subsection{AEPSs in relation to the energy efficiency potential in industry}

In relation to the EU 2020 primary energy target, it states that the EU is to decrease energy intensity with $3.3 \%$ per year, and that e.g. the major energy efficiency potential in industry, stated by the commission to be $25 \%$, is found in the generic process such as fans and lighting (EC, 2006b). However, while this is the case in the EU industry as a whole, in 
regions with a large share of energy-intensive heavy process industry, this fails to fully hold, e.g. Sweden, with $75 \%$ of its industrial energy use coming from energy intensive industry. The different degree of energy-intensive industry in the EU Member States thus lead to an implementation asymmetry in regard to the EU 2020 primary energy target, and is an example of AEPSs.

\subsection{AEPSs in relation to climate and degree of renewability in the energy system}

Apart from various shares of energy-intensive industry in the different Member States, yet another occurrence of AEPSs in regard to the EU 2020 primary energy target is the diversity of RES among EU Member States. While the degree of RES for the EU Economy as a whole is a small portion of the aggregated energy end-use, this is not the case in all Member States. Sweden for example had a share of $39.8 \%$ of RES in its energy mix in 2005 and according to the 2020 RES-target, should have a share of $49 \%$ in 2020 . In relation to achieving a $3.3 \%$ reduction in energy intensity annually, Member States like Sweden with large degrees of RES naturally falls into an implementation asymmetry.

The Swedish building sector for example has undertaken large conversions from fossil fuels to RES. Since the beginning of the 1970ies, the share of oil consumption has decreased from $72 \%$ (1970), to less than $9 \%$ (2009), see Fig. 2. Naturally, this large conversion restricts the ability for further RES-related conversion measures, and is yet another example of an implementation asymmetry. Moreover, energy end-use efficiency measures will thus in the Swedish case include RES, and thus negatively affect the possibility for Sweden to meet the EU 2020 primary energy target.

Related to the building sector, the Swedish climate is yet another factor affecting the possibility to implement energy end-use efficiency measures. For example Near-Zero Energy Buildings (N-ZEB), specified in the Energy Performance of Building Directive (EPBD), see EC (2010), will naturally be more difficult and costly to build in Member States like Sweden with a cold climate, compared with, e.g. central Europe. 
Yet another example of AEPSs is the Swedish PPI. If aiming to achieve a more efficient use of biomass in the Swedish PPI (Pulp- and Paper Industry), a sector which accounts for half of the Swedish industrial energy use. This is a direct contradiction to the fulfilment of the target of increasing shares of RES in Sweden from $39.8 \%$ (2005) to $49 \%$ (2020).

\subsection{AEPSs in relation to research of technological development}

In relation to AEPSs, yet a third challenge is research of technological development. Utterback (1996) state that technological development often is taken through a number of phases before transitioning into a phase with strong competition among a few large market actors. In relation to the EU 2020 primary energy target, it is evident that a strong emphasis on achieving energy savings in a sector which has reached this mature state is limited. This is due to that through the years, actors with limited success in regard to cost-reductions, where energy efficiency definitely is one of the major cost-reduction areas among energyintensive industries, have already been forced to leave the market. Research of Swedish PPIs states that: "The PPI's respondents feel that their industry has gone through - and is still going through - a globalisation and consolidation phase that has led to tougher competition, which in turn exposes the companies to constant pressure to improve their cost-effectiveness." (Sandberg, 2004; Möllersten 2002). Moreover, research states that the major energy cost increases for Swedish industry has led to shut down of PPIs (Thollander and Ottosson, 2010).

In conclusion, actors still on the market in mature industries may to some extent already be seen as efficient in regard to for example energy use. Moreover, these mature industries, e.g. energy-intensive industries like pulp- and paper, iron- and steel, etc. often deliver a lower degree of added value than other less mature industries.

2.4 Implications of AEPSs in relation to energy end-use policy cost-effectiveness 
In relation to the three outlined examples of AEPSs, the cost-effectiveness of different energy end-use policies would indicate the risk for individual Member States of facing the occurrence of AEPSs or not. Research on the cost-effectiveness of the two current major industrial energy end-use policies in place in Sweden indicate a cost-effectiveness of 200$400 \mathrm{kWh} /$ EUR for the Swedish energy audit program directed towards small- and mediumsized and non-energy-intensive industries (Thollander and Dotzauer, 2010), i.e. industries where the major energy efficiency opportunities is found in the generic process such as fans and lighting as stated by EC (2006b). However, the cost-effectiveness for the Swedish LTA (Long Term Agreement) program PFE, directed towards the electricity-intensive industry, is around $10 \mathrm{kWh} / \mathrm{EUR}$ for (Thollander and Rohdin, 2010). It is thus evident from this comparison of cost-effectiveness of energy policies towards energy-intensive and nonenergy-intensive industry in place that AEPSs in fact will be a key challenge for some Member States and the EU to resolve. In summary, fulfilling the EU 2020 primary energy target will due to occurrence of AEPSs be considerably more costly for Sweden.

In summary, EU Member States with i) large shares of energy-intensive industry; ii) large shares of mature industrial sectors; iii) large degrees of RES in the energy mix will have to take a more costly approach to achieve the EU 2020 primary energy target due to the existence of AEPSs.

AEPSs are also likely to occur for Member States with a large need for space heating or space cooling.

\section{Towards a more effective energy policy formation}

The above outlined examples of challenges in relation to AEPSs outline the need for effective energy police formation. The following chapter presents three means of moving towards more effective energy policies in a Swedish perspective, some of which are directly related to AEPSs. 
3.1 Moving from project-based approach (PBA) towards a long-term energy policy approach (LTEPA)

One major trend in Sweden's energy policy mix is its project-based approach (PBA). While a PBA, from a socio-economic point of view, may be seen as the most efficient low risk option of introducing energy policies, it does create a culture where energy efficiency is perceived to not be of major concern to the government, e.g. an investment subsidy or an information policy runs for a few years if the budget is not exceeded, and is then terminated. Taken that the policy exceeds the budget before the policy is planned to be terminated, there are examples of policies which has been terminated even before schedule. The PBA have implications of the cost-effectiveness of energy policies as research indicates high overhead costs for initiating an energy policy, e.g. $40 \%$ overhead costs, or more for programs which last only a few years (Thollander et al., 2007). These overhead costs are related to formulating new laws, program set-up, marketing of the new policy etc. The PBA thus clearly increases governmental expenditures for policies and decrease costeffectiveness of energy policies. An example of a non-PBA, and which is one of the most cost-effective energy programs in Europe, is the Finnish Motiva, which has lasted since the early 1980ies (Väisänen, 2003). Yet another example of a successful non-PBA approach is the world's largest industrial energy program, the American IAC (Industrial Assessment Centre), including more than 10,000 industrial companies from the late 1970ies up until today (Andersson and Newell, 2004).

The public sector is in the ESD stated to have a role-model position in the move towards a $9 \%$ energy efficiency increase from 2008 to 2016. However, the PBA for energy policy design in Sweden contradicts partly to this aim. One main challenge for the Swedish government is thus to work strategically and move towards a Long-Term Energy Policy Approach (LTEPA) with policies lasting more than a few years. One means towards an increased LTEPA is to formulate annual goals for how much energy that should be saved 
for the industrial and building sectors each year. Such annual goals are currently lacking in Sweden.

A move from a non-PBA towards a LTEPA is however not unproblematic, e.g. in the transition from a PBA to an LTEPA, a number of institutional barriers has to be overcome. For example, such a transition to a LTEPA implies the formulation of a new law, a process which takes several years to achieve. More importantly, energy policy decision-making in open democratic societies is often coupled to the current government. One means to facilitate a move towards a LTEPA and help reduce this institutional barrier would be for the EU to set up an independent organisation with expert competence in regard to policy formulation supporting the national governments in their policy-making process. Today, this expert competence is held within the nation's governmental ministries and these are directly serving under the current political leadership. Such an external organisation could also support governments in avoiding adopting polices which have had a low costeffectiveness in other Member States.

\subsection{Energy efficiency potential not equivalent to degree of implementation}

The scientific literature on the issue of energy efficiency potential versus actual outcome of an energy program is scarce. By showing great energy efficiency potentials of new energy efficient technologies, researchers may sometimes create a picture of energy efficiency potential being equivalent to degree of implementation. The world's largest industrial energy program covering more than 10,000 industrial companies, the American IAC (Industrial Assessment Centre), for example have an implementation rate of $50 \%$, i.e. half of the proposed measures from the energy audits were in fact implemented (Corbett et al., 2009; Andersson and Newell, 2003). Evaluation of Sweden's largest industrial program finds an implementation rate of $22 \%$ already implemented and $44 \%$ including planned measures (Thollander et al., 2007), while the Australian EEAP shows an implementation rate of $82 \%$. However, Harris et al (2000)'s results were not based on the full energy 
efficiency potential. Instead, a few selected technology investments (in average six proposed measures) were more thoroughly investigated. Improving energy efficiency with $20 \%$ from a stated potential of about $25 \%$ and $27 \%$ respectively means an $80 \%$ adoption level is to be reached. So far, research has shown that an $80 \%$ adoption level of the full energy efficiency potential in an energy program, very seldom is reached, i.e. an $80 \%$ adoption level has to the author's awareness not been reached in any European energy programs towards the industrial and building sectors.

\subsection{Designing energy policies differently for different sectors}

One challenge is to formulate policies differently for various sectors (Ramirez et al., 2005). Otherwise, this may lead to energy polices being designed alike, independent of which sector the policy targets. This challenge may be explained by research on barriers to energy efficiency which reveal that the barriers differ between sectors (Rohdin and Thollander, 2006; Rohdin et al., 2007; Thollander and Ottosson, 2008). One such example is energy audits and energy networks. The former, energy audits, are according to the European Commission and the ESD (EC, 2006b) started to be a major means for increasing energy efficiency in European SMEs. However, an energy audit program towards the energy-intensity heavy process industry may not be the most optimal policy choice. Partly due to vast amount of time needed for data collection, and partly due to the fact that an auditor, with limited time set off for the mission, may not be able to fully include the complexity of the industry's energy systems in the analysis. These two factors may lead to a low cost-effectiveness of such a policy, i.e. a clean-cut energy audit program towards energy-intensive industry may be less cost-effective than energy audits towards industrial SMEs, as shown by e.g. Thollander and Rohdin (2010).

In regard to energy networks, a type of information policy which has become more common in a number of local, regional, or sector-specific Swedish programs, is derived from the success in the energy-intensity industry. In this sector, energy controllers, experts 
in their field, meet and shares experiences and pros and cons with various technology options. However, energy networks in non-energy intensity sectors such as SMEs are likely to fail as there are, either no person assigned for energy controlling, or because the person in charge do not have the time needed, or the knowledge (Shipley and Elliot, 2001). In summary, the difficulty of assimilation information among industrial SMEs may be seen as one of the major barriers, not solely lack of information, e.g. (Schleich and Gruber, 2009; Thollander et al., 2007; Shipley and Elliot, 2001). Evaluation of energy information programs towards households reveal that information programs led to increased knowledge of the negative environmental effects coupled to individual energy use. However, change in actual behaviour or investment patterns where shown to be scarce (Stern and Aronsson, 1984). In summary, this leads to potential failures of energy information programs including energy networks towards low energy-using sectors.

\section{Concluding discussion}

The aim of this article has been to present major challenges related to the formation of energy policies towards the Swedish industrial and building sectors in order to fulfil the EU 2020 primary energy target. Results show that the Swedish industrial and building sectors will have difficulty reaching the EU 2020 primary energy target as Sweden have a large degree of energy-intensive industry, a sector which may be viewed as mature in terms of technological development, and which have a large degree of RES in the industrial and building energy mix. The challenge for Sweden to reach the EU 2020 primary energy target, compared to the EU as a whole, with the differences outlined above is defined as an Asymmetric Energy Policy Shock (AEPS). The fact that Sweden's 2020 energy targets deviates from the EU 2020 primary energy targets underscores the existence of AEPSs. By comparing the cost-effectiveness of different energy policies in Sweden, the paper results prove the existence and risk of AEPSs, and shows that AEPSs, in fact, will be a key 
challenge for Sweden to resolve, in order to effectively fulfil the EU 2020 primary energy target.

Results from this paper may be able to generalize beyond the scope of the Swedish industrial and building sectors. Related to AEPSs, the paper shows that the EU 2020 primary energy target will be more difficult to reach for a Member State with e.g. large shares of energy-intensive industry; large shares of mature industrial sectors and large degrees of RES in the energy mix.

The paper shows that moving from a project-based policy approach (PBA) towards a long-term energy policy approach (LTEPA) is of outmost importance for Sweden. Moreover, the paper emphasise that the implementation rate of a policy or a program is not equivalent to the energy efficiency potential. Research has shown that an $80 \%$ implementation rate, based on the full energy efficiency potential in any energy program, very seldom is reached. In summary this remains yet another key challenge to fulfilling the EU 2020 primary energy target.

Finally, prior to a policy being implemented the paper emphasize that AEPSs should not be neglected in the policy analysis process, and is suggested to be included in the policy analysis process together with the market failure approach. In conclusion, overcoming AEPSs, and moving towards a LTEPA will be of key importance for individual Member States like Sweden, if the 2020 primary energy target is to be fulfilled.

\section{References}

Anderson, S.T., Newell, R.G., 2004. Information programs for technology adoption: the case of energyefficiency audits. Resource and Energy Economics 26 (1), 27-50.

Churchman, C.W., 1968. The systems approach. Dell Publishing Co. Inc., New York. 
Corbett, C., Muthulingam, S., Benartzi, S., Oppenheim, B., 2009. Adoption of Profitable Energy Efficiency Related Process Improvements in Small and Medium Sized Enterprises. In: Proceedings of the 5th European conference on economics and management of energy in industry (ECEMEI-5).

EC (European Commission), 2010. Directive 2010/31/EU of the European Parliament and of the Council of 19 May 2010 on the energy performance of buildings, Brussels.

EC (European Commission), 2006a. Directive 2006/32/EC of the European Parliament and of the Council of 5 April 2006 on energy end-use efficiency and energy services and repealing Council Directive 93/76/EEC, Brussels.

EC (European Commission), 2006b. Communication from the Commission. Action Plan for Energy Efficiency: Realizing the Potential. COM (2006) 545 final.

EEPO (European Electricity Prices Observatory), 2003. Year 2002 Results. European Electricity Prices Observatory (EEPO), Brussels.

EMU-investigation, 1996. Sverige och EMU [Sweden and EMU]. SOU 1996:158, Ministry of Finance, Stockholm. [in Swedish]

GB (Government Bill), 2009. En sammanhållen energi- och klimatpolitik [An aggregated energy- and climate politic]. Prop. 2008/09:163. Stockholm. [in Swedish]

Harris, J., Anderson, J., Shafron, W., 2000. Investment in energy efficiency: a survey of Australian firms. Energy Policy 28 (12), 867-876.

IEA (International Energy Agency), 2011. Key World Energy Statistics 2010. Paris.

Möllersten, K., 2002. Opportunities for CO2 Reductions and CO2-Lean Energy Systems in Pulp and Paper Mills. Royal Institute of Technology, Dissertations ISSN 1104-3466, Stockholm. 
NordPool, 2011. The homepage of the Nordic Power Exchange. Retrieved September, 2011, from: http://www.nordpool.no

Ramirez, C.A., Patel, M., Blok, K., 2005. The non-energy intensive manufacturing sector. An energy analysis relating to the Netherlands. Energy 30 (5), 749-767.

Rohdin, P., Thollander, P., 2006. Barriers to and Driving Forces for Energy Efficiency in the Non-energy Intensive Manufacturing Industry in Sweden. Energy 31 (12), 1836-44.

Rohdin, P., Thollander, P., Solding, P., 2007. Barriers to and drivers for energy efficiency in the Swedish foundry industry. Energy Policy 35 (1), 672-77.

Sandberg, P., 2004. Optimisation and Co-operative Perspectives on Industrial Energy Systems. Linköping Studies in Science and Technology. Dissertations, ISSN 0345-7524; 913, Linköping.

Schleich J, Gruber E., 2008. Beyond case studies: barriers to energy efficiency in commerce and the services sector. Energy Economics 30, 449-64.

SEA (Swedish Energy Agency), 2010a. Energy in Sweden 2010. Swedish Energy Agency Publication Department, Eskilstuna.

SEA (Swedish Energy Agency), 2010b. Underlag till den andra handlingsplanen - Uppföljning av energibesparingsmålen enligt Energitjänstedirektivet [Background for the second energy efficiency action - follow-up of the energy saving targets according to the energy end-use efficiency and energy services directive]. ER 2010:32. Swedish Energy Agency Publication Department, Eskilstuna. [in Swedish]

Shipley, A.M., Elliot, R.E., 2001. Energy Efficiency Programs for Small and Medium Sized industry. In: Proceedings of the 2001 ACEEE summer study on energy efficiency in industry, vol. 1. American Council for an Energy-Efficient Economy, 183-196.

Stern, P.C., Aronsson, E. (Eds.), 1984. Energy Use: The Human Dimension, New York. 
The Swedish Ministry of Enterprise, Energy and Communications, 2001. Effektivare energianvändning \{More effective energy use], Ds 2001:60. Stockholm. [in Swedish]

Thollander, P., Dotzauer, E., 2010. An energy efficiency program for Swedish industrial small- and mediumsized enterprises. Journal of Cleaner Production 18 (13), 1339-1346.

Thollander, P., Ottosson, M., 2010. Energy management practices in Swedish energy-intensive industries. Journal of Cleaner Production 18 (2), 125-133.

Thollander, P., Rohdin, P., 2010. Cost-Effectiveness of Energy Programs involving Energy Audits - Results from Sweden. In Proceedings of the International Energy Program Evaluation Conference (IEPEC) 2010, Paris.

Thollander, P., Ottosson, M., 2008. An energy efficient Swedish pulp and paper industry - exploring barriers to and driving forces for cost-effective energy efficiency investments. Energy Efficiency 1 (1), 21-34.

Thollander, P., Rohdin, P., Danestig, M., 2007. Energy policies for increased industrial energy efficiency: Evaluation of a local energy programme for manufacturing SMEs. Energy Policy 35 (11), 5774-83.

Utterback, J. M., 1996. Mastering the dynamics of innovation. Harvard Business School Press, Harvard.

Vedung, E., 1998. Utvärdering i politik och förvaltning. [Evaluation in Policy and Administration]. Studentlitteratur, Lund. [in Swedish].

Wesselink, B., Harmsen, R., Eichhammer, W., 2010. Energy Savings 2020. How to triple the impact of energy savings in Europe. Final version. Download 17 May, 2011 at: http://www.roadmap2050.eu/attachments/files/1EnergySavings2020-FullReport.pdf

Väisänen, H., (co-ordinator), 2003. Guidebook for Energy Audit Programme Developers. Retrieved March 22, 2010, from: http://www.motiva.fi/ en/projects_and_campaigns/save_ii_-projects. 
${ }^{1}$, e.g. Utterback, 1996. 